\title{
Topology Optimization for Effective Use of Additive Manufacturing Technology
}

Key Words: Topology Optimization, Additive Manufacturing, Porous Materials, Lattice Structure, Composite Materials

\section{1. 緒言}

近年、積層造形 (Additive Manufacturing) 技術の普及が急 速に進んでいる。この方法は、従来の鋳造や鍛造、切削加 工では製造が難しかった複雑形状も造形可能であり、極め て自由度の高い製造手法として注目を集めている。特に近 年の技術進歩により、金属材料やマルチマテリアル樹脂に おいても微細な造形が可能になっている1)。

他方、数值計算を活用し、優れた最適構造を高い自由度 で導出可能なトポロジー最適化という技術がある2)。トポ ロジー最適化では中空構造を含む複雑な形状が最適解とし て導出される可能性があるが、積層造形を用いればその直 接の実現も難しくはない。このようなトポロジー最適化と 積層造形を組み合わせた活用法として、本論文では高性能 ポーラス材料の開発について紹介する。

まずポーラス材料は軽量 · 高剛性・高衝撃吸収能・大表 面積といった特徵を活用し、人工骨や熱交換器への応用 が研究されてきたが、その製造法は材料溶融時の発泡によ るものが主であり、内部構造の詳細な制御は困難であっ た。ポーラス材料の性能は内部構造に大きく依存するため、 ポーラス材料において、意図した性能の定量的な実現は大 きな課題であったと言える。それに対し、積層造形技術を 適用すれば、意図した形状の内部構造を持つポーラス材料 の製造が可能になるため、新たな高性能ポーラス材料の開 発が期待できる。

ただし、ポーラス材料の設計法として、単純な形状及び 基礎的な力学特性に関して簡易な力学モデルが提案されて いるものの3)、空間を自由に活用し最大限の性能を発揮させ ることは、人手による設計では難しい。それに対し、数值 計算を活用し、優れた最適構造を高い自由度で導出可能な トポロジー最適化を用いればより高性能化が図れる。また、 ポーラス材料の実効的 (effective、もしくは見かけ上の、巨 視的な、マクロ) 性能は、均質化法 ${ }^{4}$ を用いて内部構造より
計算が可能である。すなわち、トポロジー最適化を均質化 法で求められる実効的物性值の向上を目的として行うこと により、高性能を実現する任意のポーラス材料内部構造が 得られる。

以上の方法論で成された研究として、例えば、再生医療 に用いる Scaffold の剛性・浸透率の最適設計5)、人工骨用に

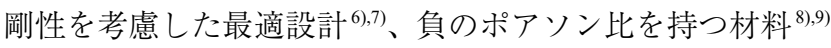
等が挙げられる。

そこで本論文では、上記の方法論に基づき、著者が実施 した研究例として、金属積層造形を用いた軽量高剛性材料 の開発、マルチマテリアル樹脂積層造形を用いた熱収縮材 料の開発 ${ }^{10)}$ について紹介する。

\section{2. 均質化法による実効的物性値の評価}

本研究では、高剛性材料の開発において実効的剛性を考 慮し、負熱膨張材料の開発においてはさらに実効的線膨張 係数を考慮する。開発するポーラス材料は単位構造が周期 的に配置されたものを考え、このような規則構造の実効的 物性值は均質化法で導出することができる。その計算にあ たり、まずポーラス内部構造における弾性変形問題におい て、熱ひずみを含む応力ーひずみ関係が以下のフックの法 則で表されると考える。

$$
\sigma_{i j}=C_{i j k l}\left(\varepsilon_{k l}-\Delta T \alpha_{k l}\right)=C_{i j k l} \varepsilon_{k l}-\Delta T \beta_{i j}
$$

ここで、 $\sigma 、 C 、 \varepsilon 、 \alpha$ 及び $\beta$ はそれぞれ応力テンソル、弾 性テンソル、ひずみテンソル、線膨張係数テンソル、単位 温度変化あたりの熱応力テンソルである。また、 $\Delta T$ は温度 変化である。さらに、周期配置された単位領域 $Y$ を考慮し、 実効的弾性テンソル $C^{H}$ 、実効的線膨張係数テンソル $\alpha^{H}$ 、 実効的熱応力テンソル $\beta^{H}$ は以下のように計算できる。

$$
C_{i j k l}^{H}=\frac{1}{|Y|} \int_{Y}\left(C_{i j k l}-C_{i j p q} \frac{\partial \chi_{p}^{k l}}{\partial y_{q}}\right) \mathrm{d} Y
$$

*広島大学大学院工学研究科 輸送・環境システム専攻 († 739-8527 広島県東広島市鏡山 1-4-1)

Department of transportation and environmental engineering, Graduate school of Engineering, Hiroshima University

(1-4-1 Kagamiyama, Higashi-Hiroshima, Hiroshima 739-8527 Japan) 


$$
\alpha_{i j}^{H}=\left[C_{i j k l}^{H}\right]^{-1} \beta_{i j}^{H}=\left[C_{i j k l}^{H}\right]^{-1} \frac{1}{|Y|} \int_{Y}\left(\beta_{p q}-C_{p q k l} \frac{\partial \psi_{k}}{\partial y_{l}}\right) \mathrm{d} Y
$$

ここで、 $\chi と \psi は$ はそれぞれ特性変位、特性温度変位であ り、周期的境界条件の下で以下の式を解くことで得られる。

$$
\begin{gathered}
\int_{Y} C_{i j p q}\left(\delta_{p k} \delta_{p l}-\frac{\partial \chi_{p}^{k l}}{\partial y_{q}}\right) \frac{\partial v_{i}}{\partial y_{j}} \mathrm{~d} Y=0 \\
\int_{Y}\left(\beta_{i j}-C_{i j k l} \frac{\partial \psi_{k}}{\partial y_{l}}\right) \frac{\partial v_{i}}{\partial y_{j}} \mathrm{~d} Y=0
\end{gathered}
$$

\section{3. トポロジー最適化}

トポロジー最適化の基本的な考え方は、固定設計領域と 次式に示す特性関数 $\chi_{\Omega}$ の導入にある。すなわち、最適構造 $\Omega_{d}$ を含む固定設計領域 $D$ を最初に設け、その固定設計領 域と特性関数 $\chi_{\Omega}$ を用いて、最適化問題を材料分布問題に置 き換えることにある。

$$
\chi_{\Omega}(\mathbf{x})=\left\{\begin{array}{lll}
1 & \text { if } & \mathbf{x} \in \Omega_{d} \\
0 & \text { if } & \mathbf{x} \in \mathrm{D} \backslash \Omega_{d}
\end{array}\right.
$$

上式の $\chi_{\Omega}$ を用いれば固定設計領域 $D$ 内の座標 $\mathbf{x}$ におけ る $\chi_{\Omega}$ の 0-1 問題として、最適構造を決定することができる。 しかし、この式に基づいて最適化を行う場合には、固定設 計領域 $D$ 内の全ての座標 $\mathbf{x}$ において、不連続関数 $\chi_{\Omega}$ を評 価するという、無限個の設計変数について不連続值を扱う 問題になり、数学的に最適解が存在しないことが証明され ている。この問題は、特性関数に関する最適化問題を、大 域的な意味で連続な密度関数の最適化問題に置き換えるこ とで解決され、その緩和法としては SIMP 法 ${ }^{2)}$ が代表的で ある。これらの方法では、緩和された最適化問題は、空孔 を模した非常に弱い材料と母材とで構成される複合材料に おける、母材の体積含有率の最適化問題と解釈できる。こ のような最適化問題においては、構造か空孔か判断が困難 なグレーの領域がしばしば生じるが、SIMP 法はこの複合 材料における体積含有率を示す密度関数と物性值との関係 の非線形性をパラメータにより調整でき、明確な構造を得 易いという利点があるため、多くの研究で用いられている。 そのため、本研究でもトポロジー最適化法として SIMP 法 を用いる。

まず、金属積層造形を用いた高剛性ポーラス材料の開発 に対して、ヤング率を以下の式で表す。

$$
E(\phi)=\phi^{3} E_{0}
$$

ここで、 $\phi$ は連続関数で近似した特性関数であり、仮想 的な材料密度と解釈できる。また、 $E^{*}$ は最適構造における ヤング率、 $E_{0}$ は原材料のヤング率である。

さらに、マルチマテリアル樹脂積層造形を用いた熱収縮
材料の開発においては、材料の有無を表す関数 $\phi_{1}$ に加え、 材料の種類を表す関数 $\phi_{2}$ を導入し、ヤング率 $E$ 及び線膨張 係数 $\alpha$ を以下ように表す。

$$
\begin{gathered}
E\left(\phi_{1}, \phi_{2}\right)=\phi_{1}^{3}\left\{\phi_{2} E_{1}+\left(1-\phi_{2}\right) E_{2}\right\} \\
\alpha\left(\phi_{2}\right)=\phi_{2} \alpha_{1}+\left(1-\phi_{2}\right) \alpha_{2}
\end{gathered}
$$

ここで、 $E_{1,2}$ 及び $\alpha_{1,2}$ はそれぞれ材料 $1 、 2$ のヤング率及 び線膨張係数である。

\section{4. 最適化問題の設定}

本研究では、高剛性材料の開発においては等方的な剛性 を実現するものとする。これは、弾性テンソルにおいて垂 直応力に対応する成分と、せん断応力に対応する成分が独 立な二つの変数で表される必要がある。そのため、等方性 からのずれを表現するペナルティ項を目標関数に加える。 そして、等方性が実現されている仮定の下、体積弾性率の 最大化を目指す。ポーラス単位構造の総体積を制約条件と し、最適化問題を以下のように表す。

$$
\underset{\phi}{\operatorname{minimize}}-\sum_{i=1}^{3} \sum_{j=1}^{3} C_{i j}^{H}-\alpha \operatorname{Error}(i=1,2,3)
$$

Subject to

$$
\begin{gathered}
\frac{\int_{\Omega} \phi \mathrm{d} x}{\int_{\Omega} \mathrm{d} x} \leq v f_{\max } \\
0 \leq \phi \leq 1
\end{gathered}
$$

ただし、

$$
\text { Error }=\frac{1}{6} \sum_{i=1}^{3} C_{i i}^{H}-\frac{1}{12} \sum_{i=1}^{3} \sum_{j=1}^{3}\left(1-\delta_{i j}\right) C_{i j}^{H}-\frac{1}{3} \sum_{i=4}^{3} C_{i i}^{H}
$$

また、 $v f_{\max }$ は体積含有率の上限值である。

負熱膨張材料の開発においては、等方的な熱変形を考え る。これは、最適解に幾何的な対称性を与えることで実現 できる。最適化問題は、熱応力の最小化に加えて、ある程 度の剛性を最適構造に持たせるため剛性項を与え、以下の ように定式化する。

$$
\begin{gathered}
\underset{\phi_{1} \phi_{2}}{\operatorname{minimize}}-w^{*} C_{i i i i}^{H}-(1-w)^{*} \beta_{i i}^{H}(i=1,2) \\
0 \leq \phi_{1}, \phi_{2} \leq 1
\end{gathered}
$$

以上の最適化問題において、設計変数 $\phi$ を勾配法で更新 し、最適構造を得る。Fig.1に最適化のフローチャートを 示す。

\section{5. 積層造形用のモデル作成}

積層造形においては、金属粉末や光凝固樹脂を、層ごと に選択的に溶融・凝固させ、積層させて三次元形状を造形 


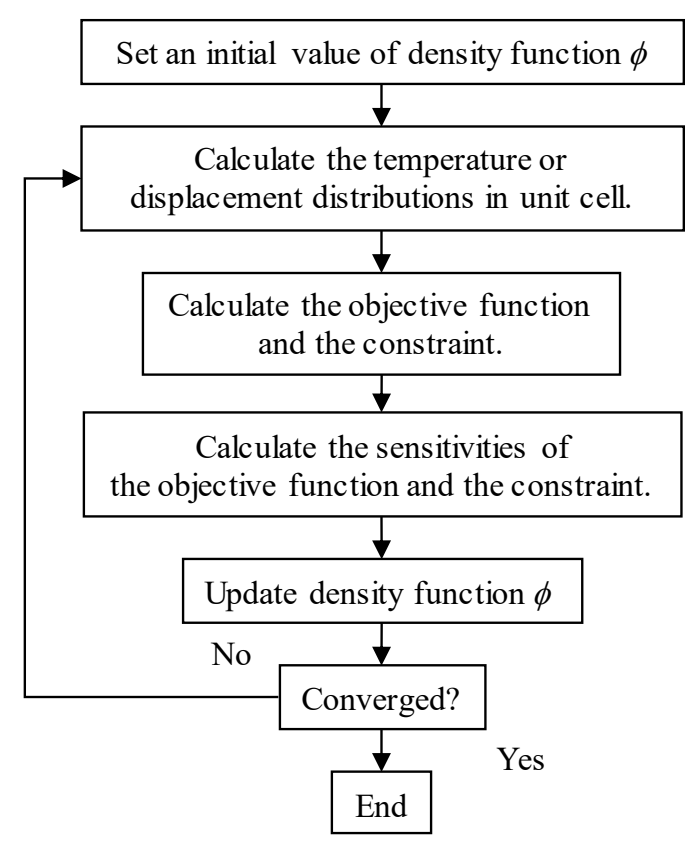

Fig.1 Flowchart of optimization algorithm.

する。そのため、造形の形状自由度が極めて高い。ただし、 装置や材料に依存して、造形物の最小厚さや許容角度等に 制約があり、それに違反するモデルは造形できない。ま た、内部の金属粉末や、樹脂サポート材を造形後に除去す るため、ポーラス材料はそれらの除去に十分な大きさを有 する空孔が互いに接続したオープンセル構造である必要が ある。積層造形用の汎用三次元データはSTL と呼ばれる形 式であり、トポロジー最適化で得られた密度分布に対して アイソサーフェスを作成し、その形状を STL ファイルとし て出力する。なお、この STL ファイル作成には FEM プリ ポストソフトウェアであるアルテアエンジニアリング社の HyperMesh を用いる。

\section{6. 金属積層造形を用いた軽量高剛性材料の開発}

まず、金属積層造形を用いて軽量高剛性材料を開発した 例を紹介する。Fig.1に示すのは、ユニットセルに等方性 を持たせつつ、体積含有率 $30 \% 、 50 \% 、 70 \%$ (気孔率 $70 \%$ 、 $50 \% 、 30 \%)$ の条件で最適化した例である。いずれも、最 適解は当初クローズドセル構造で得られたため、立方体設 計領域の対角方向に強制的に粉抜き穴を空けて最適化を実 施した。なお、ある気孔率における、ポーラス材料の実効 的物性值の限界值は Hashin-Strinkman の材料物性值境界 ${ }^{11)}$ より求めることができる。今回の最適化では、いずれの体 積含有率においても、その限界值に対して体積弾性率で約 $85 \%$ の值となった。なお、穴を除いて最適化で得られたク ローズドセル構造においてはほぼ $100 \%$ の值が得られたた め、15\%の性能低下は強制的に設けた粉抜き穴によるもの である。 (a)

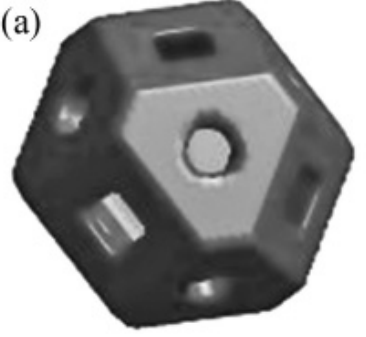

(c)

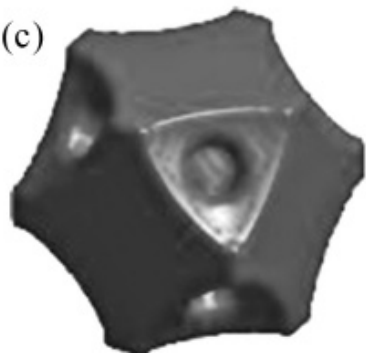

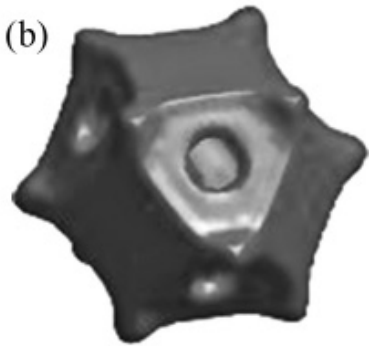

(b)

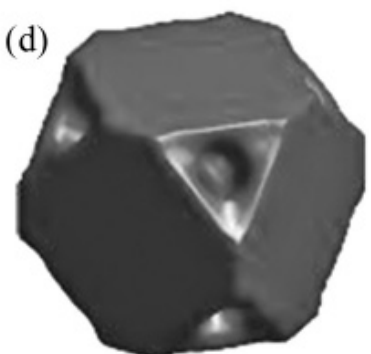

Fig.2 Initial and optimal shapes of stiffness maximization problem. (a) Initial shape. (b) $30 \%$ Volume fraction. (c) $50 \%$ Volume fraction. (d) $70 \%$ Volume fraction.

以上の最適解をもとに、材料にマルエージング鋼を用い、 レーザ溶融方式の EOS 社 EOSINT M280 で試験片を造形し た。なお、造形後には時効硬化のための熱処理を施した。 Fig.2に示すのが圧縮試験のための試験片である。ユニッ トセルの大きさを $5 \mathrm{~mm}$ とし、繰り返し配置することで 20 $\times 20 \times 30 \mathrm{~mm}$ のイイ゙で造形した。まず、全ての体積含 有率の試験片において、実効的ヤング率を計測した。 $\mathrm{n}=2$ で計測を行い、平均值でそれぞれ $27.65 \mathrm{GPa} 、 46.84 \mathrm{GPa} 、$ $66.54 \mathrm{GPa}$ とバルク材料のヤング率 $188 \mathrm{GPa}$ に対して 14.7 $\% 、 24.9 \% 、 35.4 \%$ の值が得られた。なお、シミュレーショ ンと実験との誤差は- $10.5 \% 、-7.1 \% 、-3.1 \%$ であった。 これは、粉末積層造形においては表面近傍では溶融が不十 分になり金属の密度が低下してしまうことから、全体の体 積に対する表面積の割合が大きいほど剛性が低下すること を意味していると考えられる。ただし、既存の類似研究 6),7)ではシミュレーションと実験の間に $50 \%$ 以上の著しい 乘離が見られたことを考えると本研究での誤差は許容範囲 であるといえる。なお、既存研究ではユニットセルサイズ

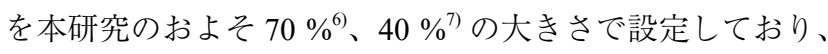
表面近くの低密度領域の影響を強く受けていたと考えられ る。

続いて、体積含有率 $30 \%$ の試験片に対して破断に至る まで圧縮試験を実施し、圧縮強度を計測した。Fig.3に示 すのが得られた実効的応力ーひずみ曲線、Fig.4に示すの が破断時の試験片画像である。 $0.2 \%$ 耐力及び圧縮強度は それぞれ平均值で $200.8 \mathrm{MPa}$ 及び $243.7 \mathrm{MPa}$ で得られた。 通常のポーラス材料のように、局所的な破壊を伴いながら 徐々に圧壊していくのではなく、ユニットセルに等しく応 
力が集中しせん断による破壊が一度に起こった。そのため、 実効的応力ーひずみ曲線においてもポーラス材料特有のプ ラトー領域と呼ばれる応力が一定のままひずみが増加する 領域は確認できなかった。ただ、局所的な破壊が起こりに くいことから、強度は通常のポーラス材料に比べて格段に 向上しており、オープンセル材料の強度を求める近似式 $\sigma_{\mathrm{ps}}^{*}=\sigma_{\mathrm{ps}} f^{3 / 2}\left(\sigma_{\mathrm{ps}}^{*}\right.$ : ポーラス材料の実効的耐力、 $\sigma_{\mathrm{ps}}$ :母材の耐力、 $f$ : 体積含有率 $)^{3)}$ と比較した際には、141.1\%もの上昇が確 認できた。すなわち、構造強度部材としての性能は、従来
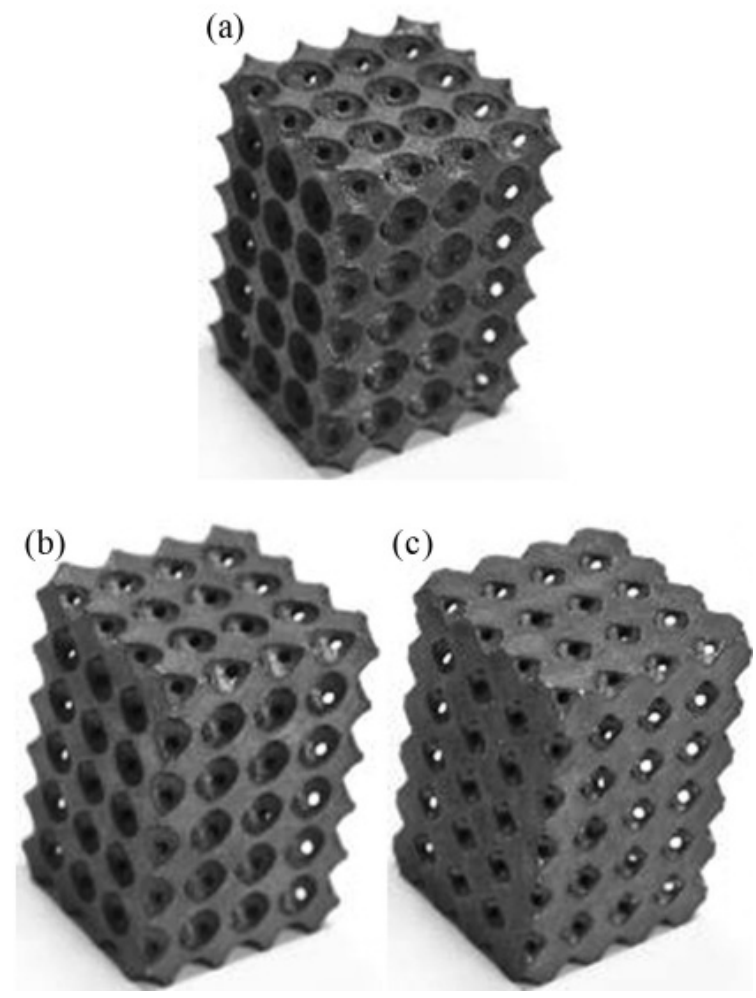

Fig.3 Pictures of test pieces fabricated by metal AM. (a) $30 \%$ Volume fraction. (b) $50 \%$ Volume fraction. (c) $70 \%$ Volume fraction.

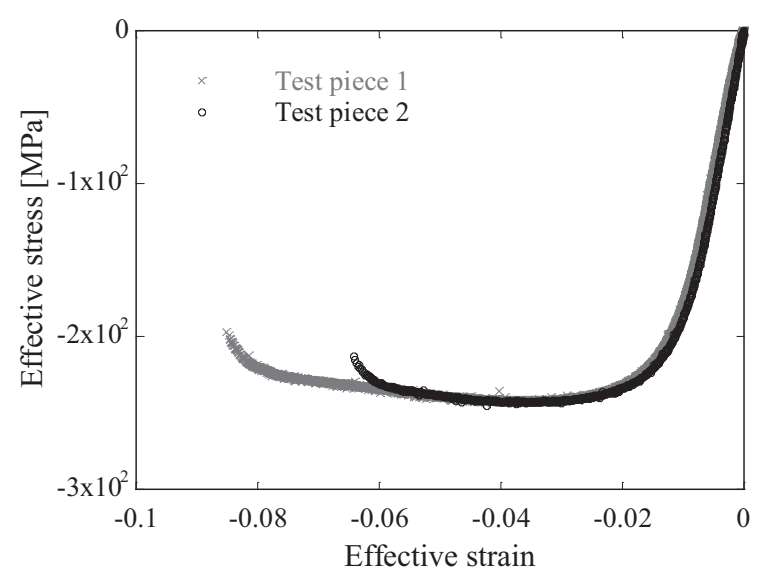

Fig.4 Effective stress - strain curves of the optimal porous with $30 \%$ volume fraction.
のポーラス材料と比較して格段に向上したことがわかる。

\section{7. マルチマテリアル樹脂積層造形を用いた負熱膨張材料 の開発}

次に、マルチマテリアル光凝固樹脂積層造形を用いて、 負熱膨張材料を開発した例を紹介する。線膨張係数が異な る複数材料を用いて、適切な形状でポーラス複合材料を構 成することにより実効的な負熱膨張が実現できることが知 られている ${ }^{12)}$ 。そこで本研究では光硬化性樹脂を用いてマ ルチマテリアルでの積層造形が可能な Stratasys 社の Objet Connex 500 を用いて、負熱膨張を示すポーラス複合材料を 開発した。本機器で利用可能な低熱膨張性材料として、ア クリルライク材料の VeroWhitePlus RGD835 を高熱膨張性材 料としてゴムライク材料の FLX9895-DMを用いた。Table 1 にこれらの材料のヤング率及び線膨張係数を示す。線 膨張係数は非常にばらついた值となったが、平均值では FLX9895-DM が VeroWhitePlus RGD835よりも高い值を示 した。また、VeroWhitePlus RGD835 と FLX9895-DM 間の 大きな剛性差も確認できた。この計測結果に基づき、式 (8) において物性值を以下のように設定する。

Fig.6 (a)にトポロジー最適化で得られた最適解を示す。 そして、最適解より抽出した STL ファイルの二次元図を

Table 1 Young's modulus and CTEs of photopolymers.

\begin{tabular}{lcccccccc} 
& $\begin{array}{c}\text { Temp } \\
(\circ \mathrm{C})\end{array}$ & $\begin{array}{l}\text { Young's modulus } \\
(\mathrm{MPa})\end{array}$ & \multicolumn{7}{l}{$\begin{array}{l}\text { CTE } \\
\left(\times 10^{-5} \mathrm{~K}^{-1}\right)\end{array}$} \\
\hline \hline Vero & 20 & 1996.2 & \pm & 111.2 & - & & \\
WhitePlus & 30 & 1023.3 & \pm & 228 & 7.14 & \pm & 0.85 \\
RGD835 & 40 & 288.5 & \pm & 34.6 & 8.96 & \pm & 1.56 \\
\hline \multirow{2}{*}{ FLX9895 } & 20 & 67.8 & \pm & 2.4 & - & & \\
DM & 30 & 13 & \pm & 5.4 & 8 & \pm & 1.64 \\
& 40 & 3.8 & \pm & 0.8 & 10.53 & \pm & 3.1 \\
\hline
\end{tabular}

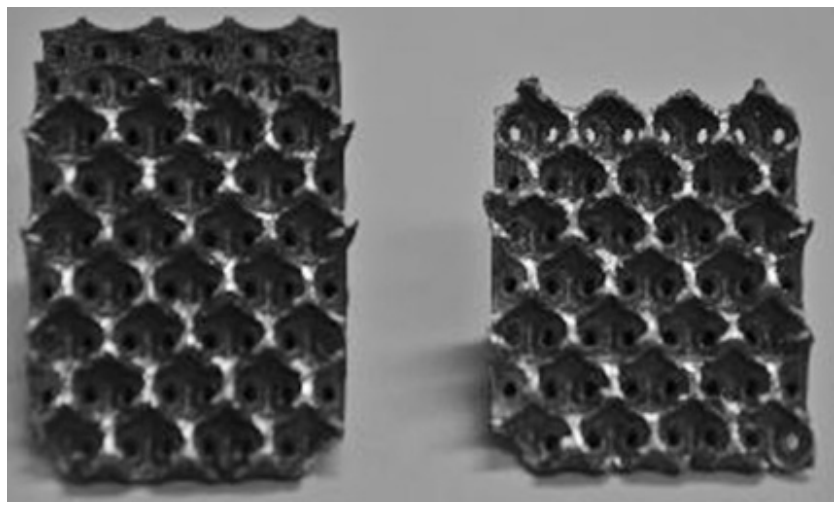

Fig.5 Pictures of broken test pieces. 


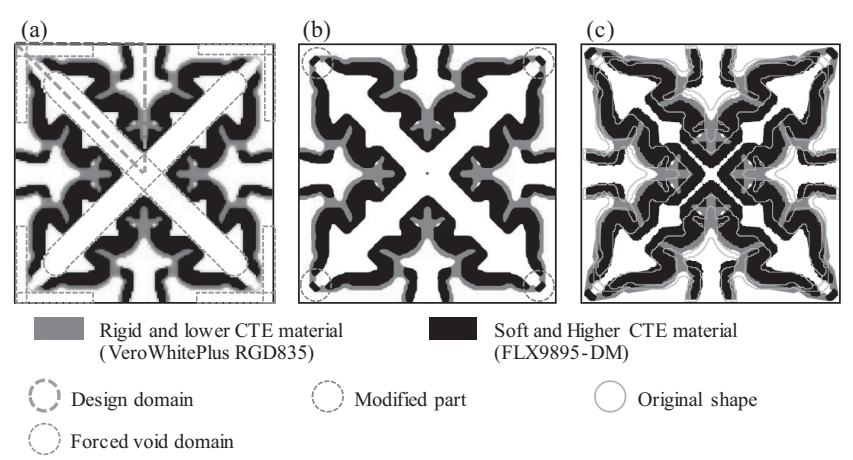

Fig.6 Optimal configurations and 2D view of the STL model. (a) Original topology optimization result. (b) 2D view of the STL model generated from the topology optimization result. (c) Thermal deformation shape obtained from the reanalysis of the STL model.

(a)

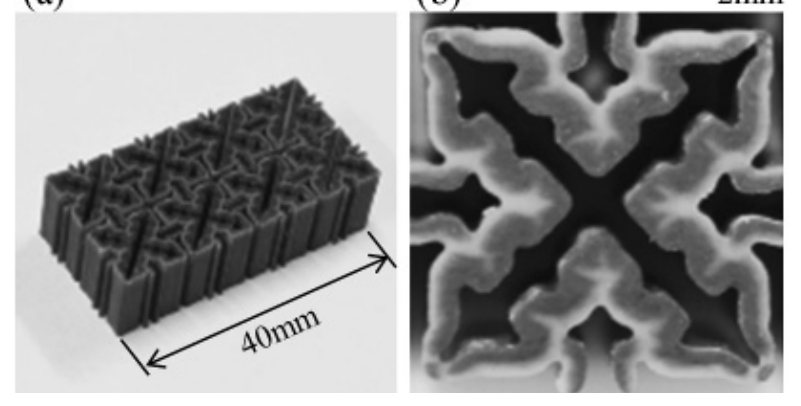

Fig.7 Picture of a test piece. (a) Outline view. (b) Close-up view.

Fig.6 (b) に示す。設計領域角付近にアクリルライク材料の 極めて細い部材が生じており、それはヒンジと解釈できる ので、ある程度の厚さを有するゴム材料で置き換えるとい う修正を施した。さらに、Fig.6 (c) に熱変形図を示す。材 料間の熱膨張差によるバイメタルに似た曲げが内部におこ り、ヒンジによるメカニズムを通じて見かけ上の熱収縮が 確かに生じた。

この最適解をユニットセル寸法を $10 \mathrm{~mm}$ として $4 \times 2$ で レイアウトし、Fig.7に示す試験片を造形した。レーザ走 査式の熱澎張計 (SL-1600A、品川リフラクトリーズ製) で長 手方向のひずみを計測した結果を Fig.8 に示す。 $\mathrm{N}=3$ の計 測に扔いて、室温から約 $40{ }^{\circ} \mathrm{C}$ の間でー $1.18 \sim-1.12 \mathrm{~K}^{-1}$ の 值が得られた。

\section{8. 結 言}

本論文では、トポロジー最適化と積層造形技術を効果的 に組み合わせる例として、両技術を用いた高性能ポーラ ス材料の開発について紹介した。基本的にはポーラス材料 の実効的物性值を目的関数としてトポロジー最適化を実施 し、得られた最適解を積層造形することにより、ポーラス 材料の実効的物性值の設計が可能である。今回紹介した高

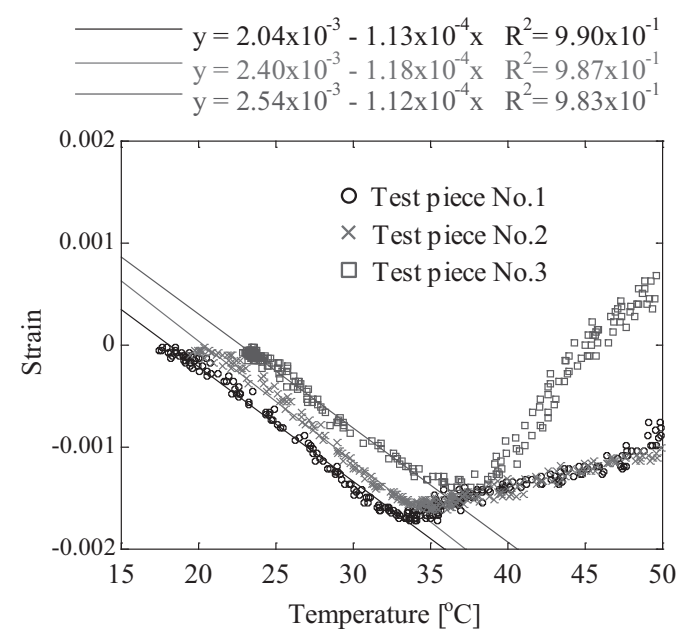

Fig.8 Axial strains of test pieces measured by a laser scanning dilatometer.

剛性材料、負熱澎張材料の開発においても、意図した機能 を実現することができた。しかし、完全な設計には未だ課 題も多い。例えば、高剛性ポーラス材料の開発において は、高強度という副次的な利点が得られたが、強度の定量 的解析及び最適設計は難しい。実用化のためには強度も含 めた最適設計技術の開発が必要であると考える。また、負 熱膨張材料の開発に抢いては、光硬化性樹脂の熱膨張特性 が不安定なことから、意図した線膨張係数值の直接の実現 は困難であった。また、ヒンジを内部構造に含むことから、 剛性が極めて低いという久点があった。これらの欠点は 金属でのマルチマテリアル積層造形が可能な Direct Energy Deposition タイプ ${ }^{13), 14)}$ の装置を用いることで改善される可 能性がある。

\section{謝 辞}

本研究はアルテアエンジニアリング株式会社のアカデ ミックオープンプログラムの支援を受け実施いたしまし た。ここに感謝の意を記します。

\section{引用文献}

1) I. Gibson, D. Rosen, and B. Stucker, Additive manufacturing technologies.: Springer, 2010.

2) M. P. B endsøe and O. Sigmund, Topology Optimization:Theory,Methods, and Applications. Berlin: SpringerVerlag, 2003.

3) L. J. Gibson and M. F. Ashby, Cellular Solids: Structure and Properties, 2nd ed.:Cambridge University Press, Aug 1999.

4) J. M. Guedes and N. Kikuchi, "Preprocessing and postprocessing for materials based on the homogenization method with adaptive finite element methods," Comput. Meth. Appl. Mech. Eng., 83 (1990) 143-198.

5) S. J. Hollister, "Porous scaffold design for tissue engineering," Nat. 
Mater., 4 (2005) 518-524.

6) C. Y. Lin, T. Wirtz, F. LaMarca, and S. J. Hollister, "Structural and mechanical evaluations of a topology optimized titanium interbody fusion cage fabricated by selective laser melting process," J. Biomed. Mater. Res., 83 (2007) 272-279.

7) D. Xiao, Y. Yang, X. Su, D. Wang, and J. Sun, "An integrated approach of topology optimized design and selective laser melting process for titanium implants materials," Bio-Med. Mater. Eng., 23 (2013) 433-445.

8) J. Schwerdtfeger et al., "Design of auxetic structures via mathematical optimization," Adv. Mater., 23 (2011) 2650-2654.

9) E. Andreassen, B. S. Lazarov, and O. Sigmund, "Design of manufacturable 3D extremal elastic microstructure," Mech. Mater., 69 (2014) 1-10.
10) A. Takezawa, M. Kobashi, and M. Kitamura, "Porous composite with negative thermal expansion obtained by photopolymer additive manufacturing," APL Mater., 3 (2015) 076103.

11) Z. Hashin, "Analysis of composite materials - a survey," J. Appl. Mech., 50 (1983) 481-505.

12) O. Sigmund and S. Torquato, "Composites with extremal thermal expansion coefficients," Appl. Phys. Lett., 69 (1996) 3203-3205.

13) W. E. Frazier, "Metal additive manufacturing: A review," J. Mater. Eng. Perform., 23 (2014) 1917-1928.

14) Q. Yang et al., "Finite element modeling and validation of thermomechanical behavior of Ti-6Al-4V in directed energy deposition additive manufacturing," Addit. Manuf., 12 (2016) 169177. 